\title{
Editorial
}

Published online: January 16, 2018

DOI: $10.1159 / 000486565$

\section{Novel Translational Research Methodology and the Prospect to a Better Understanding of Neurodegenerative Disease}

\author{
Paul G. Unschuld \\ Hospital for Psychogeriatric Medicine, Psychiatric University Hospital Zurich, Zurich, Switzerland; Institute for \\ Regenerative Medicine (IREM), University of Zurich, Zurich, Switzerland
}

Roger M. Nitsch and Christoph Hock have founded Neurodegenerative Diseases in 2004, and, thanks to their own and the editorial board's scientific expertise and untiring efforts, within a short time this journal has become a most lively and thriving meeting place in a fascinating and extremely promising subdiscipline of neuroscience. It is here where up-to-date research on neurobiological mechanisms is disseminated, offering an ever better understanding of Alzheimer (AD) and Parkinson disease, monogenetic autosomal disorders such as Huntington disease (HD), and many more disorders of the nervous system.

It is a great privilege to succeed as editor-in-chief the founding editors of this journal beginning in 2018, and I very much look forward to continue, supported by its experienced editorial board, its tradition of rapid publication of outstanding novel scientific studies.

Newly invited associate editors represent innovative methodological approaches in a dynamically expanding field, and it is based on their frontline expertise that Neurodegenerative Diseases will be able to evaluate, accept, and introduce to the scientific community the most convincing research methodologies and findings in brain studies.
Considering the development of disease-modifying therapeutic interventions for neurodegenerative brain disorders as a major goal of research, novel insights into brain changes prior to the manifestation of clinical syndromes are most promising. A better understanding of pathological sequences and neurobiological mechanisms implicated in these very early "preclinical" disease stages is regarded to lay open cellular vulnerability factors as a major factor of the etiology and pathogenesis of neurodegenerative disorders including $\mathrm{AD}[1,2]$, Parkinson [3], amyotrophic lateral sclerosis [4-6], and HD [7]. The identification of the relevant pathology in individuals at a point in time early enough for administering diseasemodifying therapy before irreversible neurodegenerative brain damage has commenced may represent a particular challenge for clinical research trials [8]. Recently published, encouraging first results of antibody-based therapy in $\mathrm{AD}$ [9] underline the potential of early and pathology-specific intervention, but also the need for improving diagnostic capabilities for detecting clinically inconspicuous individuals at increased risk.

A few hints at the research foci and most recent findings of colleagues who have followed our invitation to form the new team of Associate Editors of Neurodegen- 
erative Diseases may suffice here to evidence our emphasis on bringing together a broadly based expertise that is able both to stimulate new conceptual and methodological approaches in the field and to attract pertinent findings to be published in our journal.

Thematically, Neurodegenerative Diseases will certainly continue to focus on the investigation of molecular mechanisms and basic biology. Recent work by Magdalini Polymenidou and her group at the University of $\mathrm{Zu}$ rich points to a central role of functional and dynamic polymerization of the protein TDP-43 as a precondition of its pathological aggregation in amyotrophic lateral sclerosis, and possibly also its self-perpetuating, prionlike properties [10-12]. Wenzhen Duan is an expert in single gene mutations and autosomal dominant disorders at Johns Hopkins University [13-15]. Her own and her team's research has resulted in the hypothesis that expansion mutations as observable in HD may also have an etiological role in more frequent psychiatric diseases [16, 17], allowing for novel therapeutic approaches [18]. Gene therapy aimed at single pathological targets, as performed by Janine Reichenbach and her team at the University of Zurich [19-21], might thus attain therapeutic relevance beyond the initially targeted monogenetic disorder. Rodent models play a fundamental role to test novel mechanistic hypotheses as well as the resulting therapeutic interventions. Jan Klohs, from the Swiss Federal Institutes of Technology (ETH) and the University of Zurich, has demonstrated the potential of preclinical imaging for the determination of neurodegenerative and vascular pathology in various experimental settings [22-24].

A novel thematic focus of the Journal Neurodegenerative Diseases shall be the translation of laboratory findings to clinical research. To this effect, the state-of-the-art implementation of clinical research methodology and the establishment of informative biomarkers will play a decisive role. Adam Brickman, from Columbia University, is an expert in this emerging research field, and recent work of him and his team has substantially contributed to better understand the role of white matter pathology in $\mathrm{AD}$ $[25,26]$ and the interplay between vascular disease and $\mathrm{AD}$ pathology $[27,28]$. Considering the complexity of the clinical phenotype observable during the progression of neurodegenerative syndromes, interactive effects between genetic determination and environmental factors might be accountable $[29,30]$. Here, biological phenotypes of increased risk may provide information on genetic variation associated with sporadic $\mathrm{AD}$ and other neurodegenerative disorders [31-33]. Stephan Ripke is an expert in statistical genetics at Harvard Medical School and Charité Universitaetsmedizin Berlin. His work and methodological input were vital for the recent progress in the characterization of genetic signatures of frequent psychiatric disorders including polygenetic effects and copy number variation [34-38], which might also be informative for a better understanding of the inherited liability for neurodegenerative disease. Neuroimaging has proven valid both for the early diagnosis of neurodegenerative disorders [1,2], the noninvasive assessment of molecular and metabolic properties $[39,40]$, and also as a measure of therapeutic target engagement [9]. Recently, inferences on progression of $\beta$-amyloid-associated cognitive decline have been made using magnetic resonance imaging of local susceptibility [41]. Jun Hua is an expert in clinical neuroimaging at Johns Hopkins University. He will provide particular expertise in the application of novel techniques allowing for the quantification of vascular and functional brain changes $[42,43]$, which are frequent findings in early and preclinical AD and $\mathrm{HD}[1,7]$. Moreover, considering the impact of subcortical and hippocampal damage for the emergence of the clinical picture of various neurodegenerative disorders, a particular thematic focus will be set on neuroimaging approaches of this brain region, as established by Christine Tardif and her team at McGill University [44-46]. The standardized assessment of relevant brain changes and the investigation of their potential value for inferring on the progression of neurodegenerative disorder require novel and flexible data analysis strategies. Ender Konukoglu is an expert in mathematical and computational algorithms at ETH, and his expertise in biomedical image analysis has substantially contributed to recent advances in the prediction of individual disease courses and pathology [47-50].

We are well aware of the challenges ahead of us. Successful scientific work requires not only individual expertise, but also solid networks for a continuous exchange among the best researchers in the field and a platform where, in addition to conferences and personal communication, progress is documented for a wider interested and participating readership. Neurodegenerative Diseases will continue to be this sought-after platform, and all of us involved look forward to what promise to be fascinating developments aimed at freeing mankind of some of its most dreaded disease burdens.

Paul G. Unschuld

Editor-in-Chief Neurodegenerative Diseases, January 1, 2018 


\section{References}

1 Dubois B, Hampel H, Feldman HH, Scheltens $\mathrm{P}$, Aisen P, Andrieu S, Bakardjian H, Benali H, Bertram L, Blennow K, Broich K, Cavedo E, Crutch S, Dartigues JF, Duyckaerts C, Epelbaum S, Frisoni GB, Gauthier S, Genthon R, Gouw AA, Habert MO, Holtzman DM, Kivipelto M, Lista S, Molinuevo JL, O’Bryant SE, Rabinovici GD, Rowe C, Salloway S, Schneider LS, Sperling R, Teichmann M, Carrillo MC, Cummings J, Jack CR Jr: Proceedings of the meeting of the International Working Group, the American Alzheimer's Association on "The Preclinical State of AD," July, Washington, DC, USA. Preclinical Alzheimer's disease: definition, natural history, and diagnostic criteria. Alzheimers Dement 2016; 12:292-323.

-2 Sperling RA, Karlawish J, Johnson KA: Preclinical Alzheimer disease - the challenges ahead. Nat Rev Neurol 2013;9:54-58.

$>3$ Olanow CW, Obeso JA: The significance of defining preclinical or prodromal Parkinson's disease. Mov Disord 2012;27:666-669.

4 Gordon PH: Amyotrophic lateral sclerosis: an update for 2013 clinical features, pathophysiology, management and therapeutic trials. Aging Dis 2013;4:295-310.

5 Eisen A, Kiernan M, Mitsumoto H, Swash M: Amyotrophic lateral sclerosis: a long preclinical period? J Neurol Neurosurg Psychiatry 2014;85:1232-1238.

6 Hegedus J, Putman CT, Gordon T: Time course of preferential motor unit loss in the SOD1 G93A mouse model of amyotrophic lateral sclerosis. Neurobiol Dis 2007;28:154164.

7 Ross CA, Aylward EH, Wild EJ, Langbehn DR, Long JD, Warner JH, Scahill RI, Leavitt BR, Stout JC, Paulsen JS, Reilmann R, Unschuld PG, Wexler A, Margolis RL, Tabrizi SJ: Huntington disease: natural history, biomarkers and prospects for therapeutics. Nat Rev Neurol 2014;10:204-216.

8 Rosenblum WI: Why Alzheimer trials fail: removing soluble oligomeric beta amyloid is essential, inconsistent, and difficult. Neurobiol Aging 2014;35:969-974.

-9 Sevigny J, Chiao P, Bussiere T, Weinreb PH, Williams L, Maier M, Dunstan R, Salloway S, Chen T, Ling Y, O'Gorman J, Qian F, Arastu M, Li M, Chollate S, Brennan MS, QuinteroMonzon O, Scannevin RH, Arnold HM, Engber T, Rhodes K, Ferrero J, Hang Y, Mikulskis A, Grimm J, Hock C, Nitsch RM, Sandrock A: The antibody aducanumab reduces Abeta plaques in Alzheimer's disease. Nature 2016; 537:50-56.

10 Polymenidou M, Cleveland DW: Biological spectrum of amyotrophic lateral sclerosis prions. Cold Spring Harb Perspect Med 2017; 7:a024133.

11 Afroz T, Hock EM, Ernst P, Foglieni C, Jambeau M, Gilhespy LAB, Laferriere F, Maniecka Z, Pluckthun A, Mittl P, Paganetti P, Allain FHT, Polymenidou M: Functional and dy- namic polymerization of the ALS-linked protein TDP-43 antagonizes its pathologic aggregation. Nat Commun 2017;8:45.

12 Hock EM, Polymenidou M: Prion-like propagation as a pathogenic principle in frontotemporal dementia. J Neurochem 2016;138(suppl 1):163-183.

13 Jin J, Peng Q, Hou Z, Jiang M, Wang X, Langseth AJ, Tao M, Barker PB, Mori S, Bergles DE, Ross CA, Detloff PJ, Zhang J, Duan W: Early white matter abnormalities, progressive brain pathology and motor deficits in a novel knock-in mouse model of Huntington's disease. Hum Mol Genet 2015;24:2508-2527.

$>14$ Li Q, Li G, Wu D, Lu H, Hou Z, Ross CA, Yang Y, Zhang J, Duan W: Resting-state functional MRI reveals altered brain connectivity and its correlation with motor dysfunction in a mouse model of Huntington's disease. Sci Rep 2017;7:16742.

15 Jiang M, Peng Q, Liu X, Jin J, Hou Z, Zhang J, Mori S, Ross CA, Ye K, Duan W: Small-molecule TrkB receptor agonists improve motor function and extend survival in a mouse model of Huntington's disease. Hum Mol Genet 2013;22:2462-2470.

-16 Margolis RL, McInnis MG, Rosenblatt A, Ross CA: Trinucleotide repeat expansion and neuropsychiatric disease. Arch Gen Psychiatry 1999;56:1019-1031.

-17 Ross CA, McInnis MG, Margolis RL, Li SH: Genes with triplet repeats: candidate mediators of neuropsychiatric disorders. Trends Neurosci 1993; 16:254-260.

18 Ross CA, Kronenbuerger M, Duan W, Margolis RL: Mechanisms underlying neurodegeneration in Huntington disease: applications to novel disease-modifying therapies. Handb Clin Neurol 2017;144:15-28.

19 Wrona D, Siler U, Reichenbach J: CRISPR/ Cas9-generated p47(phox)-deficient cell line for chronic granulomatous disease gene therapy vector development. Sci Rep 2017;7: 44187.

20 Lanini LL, Prader S, Siler U, Reichenbach J: Modern management of phagocyte defects. Pediatr Allergy Immunol 2017;28:124-134.

21 Siler U, Paruzynski A, Holtgreve-Grez H, Kuzmenko E, Koehl U, Renner ED, Alhan C, de Loosdrecht AA, Schwable J, Pfluger T, Tchinda J, Schmugge M, Jauch A, Naundorf S, Kuhlcke K, Notheis G, Gungor T, Kalle CV, Schmidt M, Grez M, Seger R, Reichenbach J: Successful combination of sequential gene therapy and rescue allo-HSCT in two children with X-CGD - importance of timing. Curr Gene Ther 2015; 15:416-427.

22 Vaas M, Deistung A, Reichenbach JR, Keller A, Kipar A, Klohs J: Vascular and tissue changes of magnetic susceptibility in the mouse brain after transient cerebral ischemia. Transl Stroke Res 2017, Epub ahead of print.

23 Klohs J, Deistung A, Ielacqua GD, Seuwen A, Kindler D, Schweser F, Vaas M, Kipar A, Reichenbach JR, Rudin M: Quantitative as- sessment of microvasculopathy in arcAbeta mice with USPIO-enhanced gradient echo MRI. J Cereb Blood Flow Metab 2016;36: 1614-1624.

24 Klohs J, Politano IW, Deistung A, Grandjean J, Drewek A, Dominietto M, Keist R, Schweser F, Reichenbach JR, Nitsch RM, Knuesel I, Rudin M: Longitudinal assessment of amyloid pathology in transgenic arcAbeta mice using multi-parametric magnetic resonance imaging. PLoS One 2013;8:e66097.

25 Lee S, Viqar F, Zimmerman ME, Narkhede A, Tosto G, Benzinger TL, Marcus DS, Fagan AM, Goate A, Fox NC, Cairns NJ, Holtzman DM, Buckles V, Ghetti B, McDade E, Martins RN, Saykin AJ, Masters CL, Ringman JM, Ryan NS, Forster S, Laske C, Schofield PR, Sperling RA, Salloway S, Correia S, Jack C Jr, Weiner M, Bateman RJ, Morris JC, Mayeux R, Brickman AM; Dominantly Inherited Alzheimer Network: White matter hyperintensities are a core feature of Alzheimer's disease: evidence from the dominantly inherited Alzheimer network. Ann Neurol 2016;79:929939.

26 Gu Y, Vorburger RS, Gazes Y, Habeck CG, Stern Y, Luchsinger JA, Manly JJ, Schupf N, Mayeux R, Brickman AM: White matter integrity as a mediator in the relationship between dietary nutrients and cognition in the elderly. Ann Neurol 2016;79:1014-1025.

- 27 Tosto G, Bird TD, Bennett DA, Boeve BF, Brickman AM, Cruchaga C, Faber K, Foroud TM, Farlow M, Goate AM, Graff-Radford NR, Lantigua R, Manly J, Ottman R, Rosenberg R, Schaid DJ, Schupf N, Stern Y, Sweet RA, Mayeux R; National Institute on Aging Late-Onset Alzheimer Disease/National Cell Repository for Alzheimer Disease Family Study Group: The role of cardiovascular risk factors and stroke in familial Alzheimer disease. JAMA Neurol 2016;73: 1231-1237.

28 Schreiner SJ, Kirchner T, Narkhede A, Wyss M, Van Bergen JMG, Steininger SC, Gietl AF, Leh SE, Treyer V, Buck A, Pruessmann KP, Nitsch RM, Hock C, Henning A, Brickman A, Unschuld PG: Brain amyloid burden and cerebrovascular disease are synergistically associated with neurometabolism in cognitively unimpaired older adults. Neurobiol Aging 2017, in press.

29 Lambert JC, Ibrahim-Verbaas CA, Harold D, Naj AC, Sims R, Bellenguez C, DeStafano AL, Bis JC, Beecham GW, Grenier-Boley B, Russo G, Thorton-Wells TA, Jones N, Smith AV, Chouraki V, Thomas C, Ikram MA, Zelenika D, Vardarajan BN, Kamatani Y, Lin CF, Gerrish A, Schmidt H, Kunkle B, Dunstan ML, Ruiz A, Bihoreau MT, Choi SH, Reitz C, Pasquier F, Cruchaga C, Craig D, Amin N, Berr C, Lopez OL, et al: Meta-analysis of 74,046 individuals identifies 11 new susceptibility loci for Alzheimer's disease. Nat Genet 2013;45: 1452-1458.
Novel Translational Research Methodology
Neurodegener Dis 2018;18:1-4 DOI: $10.1159 / 000486565$ 
30 Wirth M, Villeneuve S, La Joie R, Marks SM, Jagust WJ: Gene-environment interactions: lifetime cognitive activity, APOE genotype, and beta-amyloid burden. J Neurosci 2014;34: 8612-8617.

- 31 Adams HH, Hibar DP, Chouraki V, Stein JL, Nyquist PA, Renteria ME, Trompet S, AriasVasquez A, Seshadri S, Desrivieres S, Beecham AH, Jahanshad N, Wittfeld K, Van der Lee SJ, Abramovic L, Alhusaini S, Amin N, Andersson M, Arfanakis K, Aribisala BS, Armstrong NJ, Athanasiu L, Axelsson T, Beiser A, Bernard M, Bis JC, Blanken LM, Blanton SH, Bohlken MM, Boks MP, Bralten J, Brickman AM, Carmichael O, et al: Novel genetic loci underlying human intracranial volume identified through genome-wide association. Nat Neurosci 2016;19:1569-1582.

- 32 Hibar DP, Adams HHH, Jahanshad N, Chauhan G, Stein JL, Hofer E, Renteria ME, Bis JC, Arias-Vasquez A, Ikram MK, Desrivieres S, Vernooij MW, Abramovic L, Alhusaini S, Amin N, Andersson M, Arfanakis K, Aribisala BS, Armstrong NJ, Athanasiu L, Axelsson T, Beecham AH, Beiser A, Bernard M, Blanton SH, Bohlken MM, Boks MP, Bralten J, Brickman AM, Carmichael O, Chakravarty MM, Chen Q, Ching CRK, Chouraki V, et al: Novel genetic loci associated with hippocampal volume. Nat Commun 2017;8:13624.

-33 Heck A, Fastenrath M, Coynel D, Auschra B, Bickel H, Freytag V, Gschwind L, Hartmann F, Jessen F, Kaduszkiewicz H, Maier W, Milnik A, Pentzek M, Riedel-Heller SG, Spalek K, Vogler C, Wagner M, Weyerer S, Wolfsgruber S, de Quervain DJ, Papassotiropoulos A: Genetic analysis of association between calcium signaling and hippocampal activation, memory performance in the young and old, and risk for sporadic Alzheimer disease. JAMA Psychiatry 2015;72:1029-1036.

34 Bodea CA, Neale BM, Ripke S; International IBD Genetics Consortium; Daly MJ, Devlin B, Roeder K: A method to exploit the structure of genetic ancestry space to enhance casecontrol studies. Am J Hum Genet 2016;98: 857-868.

-35 Duncan L, Yilmaz Z, Gaspar H, Walters R, Goldstein J, Anttila V, Bulik-Sullivan B, Ripke $S$; Eating Disorders Working Group of the Psychiatric Genomics Consortium; Thornton L, Hinney A, Daly M, Sullivan PF, Zeggini E, Breen G, Bulik CM: Significant locus and metabolic genetic correlations revealed in genome-wide association study of anorexia nervosa. Am J Psychiatry 2017;174:850-858.
Erk S, Mohnke S, Ripke S, Lett TA, Veer IM, Wackerhagen C, Grimm O, Romanczuk-Seiferth N, Degenhardt F, Tost H, Mattheisen M, Muhleisen TW, Charlet K, Skarabis N, Kiefer F, Cichon S, Witt SH, Nothen MM, Rietschel M, Heinz A, Meyer-Lindenberg A, Walter H: Functional neuroimaging effects of recently discovered genetic risk loci for schizophrenia and polygenic risk profile in five RDoC subdomains. Transl Psychiatry 2017;7:e997.

37 Li Z, Chen J, Yu H, He L, Xu Y, Zhang D, Yi Q, Li C, Li X, Shen J, Song Z, Ji W, Wang M, Zhou J, Chen B, Liu Y, Wang J, Wang P, Yang P, Wang Q, Feng G, Liu B, Sun W, Li B, He G, Li W, Wan C, Xu Q, Li W, Wen Z, Liu K, Huang F, Ji J, Ripke S, Yue W, Sullivan PF, O’Donovan MC, Shi Y: Genome-wide association analysis identifies 30 new susceptibility loci for schizophrenia. Nat Genet 2017;49: 1576-1583.

38 Marshall CR, Howrigan DP, Merico D, Thiruvahindrapuram B, Wu W, Greer DS, Antaki D, Shetty A, Holmans PA, Pinto D, Gujral M, Brandler WM, Malhotra D, Wang Z, Fajarado KVF, Maile MS, Ripke S, Agartz I, Albus M, Alexander M, Amin F, Atkins J, Bacanu SA, Belliveau RA Jr, Bergen SE, Bertalan M, Bevilacqua E, Bigdeli TB, Black DW, Bruggeman R, Buccola NG, Buckner RL, Bulik-Sullivan B, Byerley W, Cahn W, et al: Contribution of copy number variants to schizophrenia from a genome-wide study of 41,321 subjects. Nat Genet 2017;49:27-35.

39 Mainta IC, Perani D, Delattre BM, Assal F, Haller S, Vargas MI, Zekry DS, Frisoni GB, Zaidi H, Ratib O, Garibotto V: FDG PET/MR imaging in major neurocognitive disorders. Curr Alzheimer Res 2017;14:186-197.

40 Schreiner SJ, Kirchner T, Wyss M, Van Bergen JMG, Quevenco FC, Steininger SC, Griffith EY, Meier I, Michels L, Gietl AF, Leh SE, Brickman AM, Hock C, Nitsch RM, Pruessmann KP, Henning A, Unschuld PG: Low episodic memory performance in cognitively normal elderly subjects is associated with increased posterior cingulate gray matter $\mathrm{N}$-acetylaspartate: a (1)H MRSI study at 7 tesla. Neurobiol Aging 2016;48:195-203.

41 Ayton S, Fazlollahi A, Bourgeat P, Raniga P, $\mathrm{Ng}$ A, Lim YY, Diouf I, Farquharson S, Fripp J, Ames D, Doecke J, Desmond P, Ordidge R, Masters CL, Rowe CC, Maruff P, Villemagne VL, Salvado O, Bush AI, Life AIB: Cerebral quantitative susceptibility mapping predicts amyloid-beta-related cognitive decline. Brain 2017;140:2112-2119.
42 Cheng Y, van Zijl PC, Hua J: Measurement of parenchymal extravascular $\mathrm{R} 2{ }^{*}$ and tissue oxygen extraction fraction using multi-echo vascular space occupancy MRI at 7 T. NMR Biomed 2015;28:264-271.

43 Hua J, Miao X, Agarwal S, Bettegowda C, Quinones-Hinojosa A, Laterra J, Van Zijl PCM, Pekar JJ, Pillai JJ: Language mapping using T2-prepared BOLD functional MRI in the presence of large susceptibility artifacts - initial results in patients with brain tumor and epilepsy. Tomography 2017;3:105-113.

44 Waehnert MD, Dinse J, Schafer A, Geyer S, Bazin PL, Turner R, Tardif CL: A subject-specific framework for in vivo myeloarchitectonic analysis using high resolution quantitative MRI. Neuroimage 2016;125:94-107.

45 Tardif CL, Devenyi GA, Amaral RSC, Pelleieux S, Poirier J, Rosa-Neto P, Breitner J, Chakravarty MM; Prevent AD Research Group: Regionally specific changes in the hippocampal circuitry accompany progression of cerebrospinal fluid biomarkers in preclinical Alzheimer's disease. Hum Brain Mapp 2017, Epub ahead of print

46 Tardif CL, Gauthier CJ, Steele CJ, Bazin PL, Schafer A, Schaefer A, Turner R, Villringer A: Advanced MRI techniques to improve our understanding of experience-induced neuroplasticity. Neuroimage 2016;131:55-72.

47 Coutu JP, Lindemer ER, Konukoglu E, Salat DH; Alzheimer's Disease Neuroimaging Initiative: Two distinct classes of degenerative change are independently linked to clinical progression in mild cognitive impairment. Neurobiol Aging 2017;54:1-9.

-48 Magnain C, Augustinack JC, Konukoglu E, Frosch MP, Sakadzic S, Varjabedian A, Garcia N, Wedeen VJ, Boas DA, Fischl B: Optical coherence tomography visualizes neurons in human entorhinal cortex. Neurophotonics 2015;2:015004.

49 Konukoglu E, Coutu JP, Salat DH, Fischl B; Alzheimer's Disease Neuroimaging Initiative: Multivariate statistical analysis of diffusion imaging parameters using partial least squares: application to white matter variations in Alzheimer's disease. Neuroimage 2016;134:573-586.

50 Sabuncu MR, Konukoglu E; Alzheimer's Disease Neuroimaging Initiative: Clinical prediction from structural brain MRI scans: a largescale empirical study. Neuroinformatics 2015;13:31-46. 